\title{
The Influence of Product, Restaurant Atmosphere, Customer Value, and Customer Loyalty through Customer Statisfacation as Mediation (Case study on Choie Dimsum Surabaya)
}

\author{
Romadini Antikasari*, Agus Baktiono, I Gede Arimbawa, \& Elok Damayanti \\ Department of Management, Faculty of Economics and Business, Narotama University, Indonesia
}

\begin{abstract}
The purpose of this study was to analyze the effect of product quality, restaurant atmosphere, and customer value on customer satisfaction and customer loyalty. This type of research is quantitative. The population of this study were 95 respondents who bought at Surabaya Choie Dimsum. The analysis technique used is Partial Least Square (PLS). Data was obtained from questionnaires and tested with the SmartPLS 3.0 application. The results of this study indicate that product quality, restaurant atmosphere, and customer value have a positive and significant influence on customer satisfaction and customer loyalty. And customer satisfaction has a positive and significant influence on customer loyalty.
\end{abstract}

Keywords: Product Quality; Resto Atmosphere; Customer Value; Customer satisfaction; Customer Loyalty.

\section{Introduction}

Customer satisfaction is a feeling of pleasure or disappointment in someone who appears after comparing the performance of products that are thought of to expected performance (Kotler dan Keller, 2009). In order to be able to survive in the business world, the company must be able to improve its marketing strategy to keep its customers, one of which is the company must meet the needs and desires of customers, for example by providing the best quality. One special feature of customer loyalty is those who make purchases regularly and repeatedly. The process to reach the level of customer satisfaction begins when the customer evaluates the product or service, services, and certain programs offered by the company so that customers have specific experience about impulse buying behavior. Another thing that is not less important is the quality factor of the product being sold as well as the atmosphere and place that are comfortable influencing in the creation of customer satisfaction and loyal to make repeat purchases.

The focus of this research was on the Choie Dimsum Surabaya, located in a strategic and easily accessible area, namely on Jl. Ir. Soekarno no 27, Meer Surabaya. Dimsum Choie first opened outlets in 2012 and already has several branches in Bandung and in Jakarta because of the many dimsum enthusiasts there. Mr. Endy is the owner of Choie's dimsum.

\section{Literature Review}

\subsection{Product Quality (X1)}

Product quality is "everything that can be offered to the market to get attention, be bought, used, or consumed that can satisfy desires or needs" (Kotler dan Amstrong, 2001). Product quality is a consumer assessment of the superiority or

\footnotetext{
* Corresponding author.

E-mail address: romadini54@gmail.com (Romadini Antikasari)
} 
privilege of a product (Tjiptono, 2008). Product Quality is the totality of features and characteristics of a product or service that depends on its ability to satisfy expressed or implied needs (Kotler dan Keller, 2009).

This research explores the effect of product quality variables on customer satisfaction and customer loyalty, using product quality indicators proposed by (Kotler, 1995) namely: Good taste, product features, packaging durability.

Hypothesis 1: product quality has a significant effect on customer satisfaction

The better the quality that is given to the customer, the higher the feeling of satisfaction of the customer after buying at the Choie Dimsum Surabaya.

Hypothesis 2: product quality has a significant effect on customer loyalty

The better the quality that is given to customers, the customer will make repeated purchases at Dimsum Choie

\subsection{Restaurant Atmosphere (X2)}

Explain that store atmosphere is a combination of physical messages that have been planned. Store atmosphere can be described as a change in the planning of the purchasing environment that produces special emotional effects that can cause consumers to take action to buy (Gilbert, 2003). The store atmosphere is a planned atmosphere that fits the target market and that can attract consumers to buy (Kotler, 2005).

This study examines the restaurant atmosphere variable on customer satisfaction and customer loyalty through the restaurant's atmosphere indicators according to (Mowen, Jhonn C. dan Michael, 2002) as follows: Layout, Music, aroma, texture, building design.

Hypothesis 3: the atmosphere of the restaurant has a significant effect on customer satisfaction

The better and more comfortable the place is in the hearts of the customers, the more it will create a feeling of satisfaction for customers who have already purchased at Dimsum Choie Surabaya

Hypothesis 4: the atmosphere of the restaurant has a significant effect on customer loyalty

As good as the place and make it comfortable in the hearts of customers, the higher the level of satisfaction of customers and will make purchases repeatedly

\subsection{Customer Value (X3)}

Buchari (2007) states that customer value is the difference between total value added by consumers compared to total costs incurred. According to Kotler (2005) customer value is the difference between total customer value and total customer costs where total customer value is a set of expected benefits by customers of certain products or services and total customer costs is a set of costs expected by consumers issued to evaluate, obtain, use and dispose of products or services.

Research examines customer value variables on customer satisfaction and customer loyalty by using indicators of customer value according to (Tjiptono, 2005) as follows:

1) Emotional value, utility that comes from feeling or affective / positive emotions arising from consuming products

2) Social value, utilities obtained from the ability of products to improve consumer social self-concept

3) Quality / performance value, the utility obtained from the product due to short-term and long-term cost reduction.

4) Price / value of maney, utility obtained from the perception of the expected performance of the product or service

Hypothesis 5: customer value has a significant effect on customer satisfaction

The better the customer value obtained from the customer, the higher the level of customer satisfaction after coming and buying at Dimsum Choie Surabaya

Hypothesis 6: customer value has a significant effect on customer loyalty 
The better the customer value obtained from the customer, the higher the level of customer loyalty is to come and buy repeatedly at Dimsum Choie Surabaya.

\subsection{Customer Satisfaction (Y1)}

Customer satisfaction is a feeling of pleasure or disappointment of someone who appears after comparing the performance of the product that is thought of the expected performance (Kotler dan Keller, 2009). Consumer satisfaction is the result felt by buyers who experience the performance of a company that is in accordance with their expectations (Kotler, 2000). This study uses indicators of purchase decisions proposed by (Tjiptono, 2004) are as follows: Conformity of expectations, interest in returning, and willingness to recommend.

Hypothesis 7: customer satisfaction has a significant effect on customer loyalty

The more customers who are satisfied after making a purchase at Dimsum Choie, the more customers increase their purchases.

\subsection{Customer Loyalty (Y2)}

Customer loyalty is the person who buys, especially those who buy regularly and repeatedly, and the customer is someone who continually comes to the same place to satisfy their needs and desires by having a product or service and paying for both (Hasan, 2008). A loyal customer has specific prejudices about what to buy and from whom. The buyer is not a random event. In addition, loyalty shows the condition of the duration of time and requires that actions be less than twice (Griffin, 2005)

This study uses indicators of customer loyalty to (Griffin, 2005) namely :

1) Make purchases regularly

2) Buy between product lines and services

3) Refer to other people

4) Showing immunity to attraction.

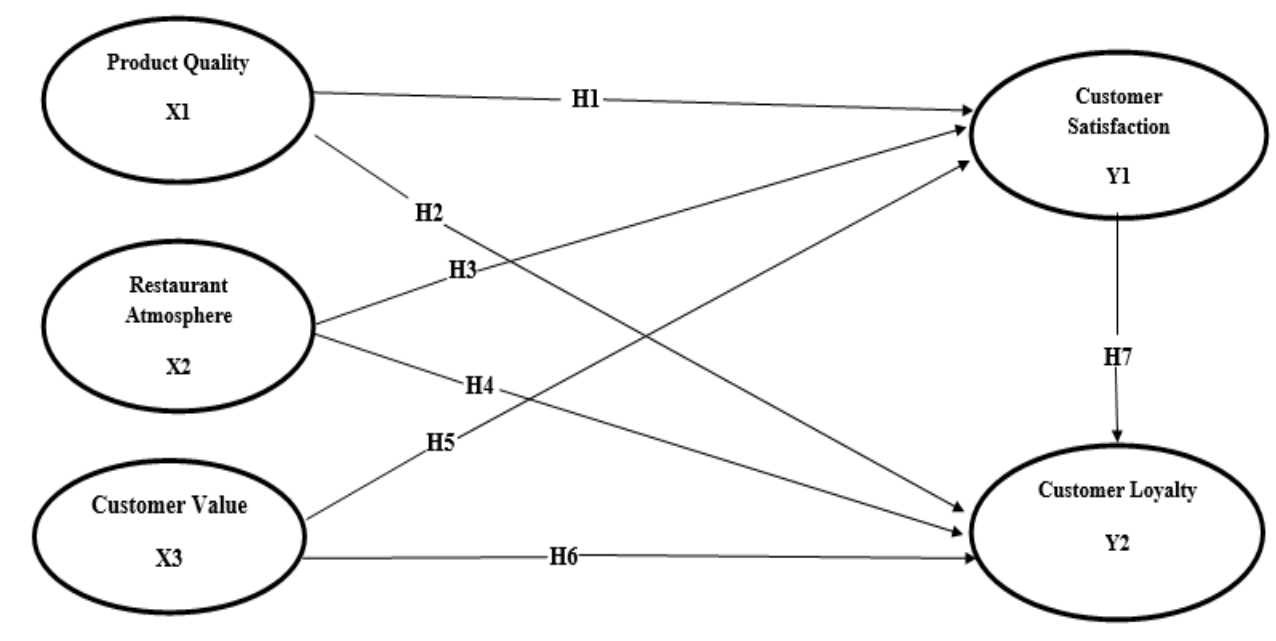

Fig. 1. Research Framework

\section{Methods}

Research uses a quantitative approach is a method based on the philosophy of positivism, used to examine the 
population or a particular sample, data collection using research instruments, data analysis is quantitative / statistical, with the aim of testing what has been determined (Sugiyono, 2008). This research variable consists of independent variables of product quality, restaurant atmosphere, and customer value. Variable intervening customer satisfaction. And the variable is tied to customer loyalty. The population in this study were 95 customers who bought at Dimsum Choie Surabaya. The data analysis technique uses Partial Least Square (PLS) with SmartPLS 3 software.

\section{Result and Discussions}

The R-Adjusted customer satisfaction variable is 0.767 . The results show that the independent variables of product quality, restaurant atmosphere, and customer value contribute $76.7 \%$ to customer satisfaction and the remaining $23.3 \%$ is influenced by other factors, while the R-Adjusted customer loyalty variable is 0828 This shows that the independent variables of product quality, restaurant atmosphere, and customer value contribute $82.8 \%$ and the remaining $17.2 \%$ is influenced by other factors.

In testing the hypothesis, a data must meet a criterion, and the hypothesis is said to be accepted if the t-statistic value is greater than $\mathrm{t}$-table $(1,661)$ and if the $\mathrm{p}$-value is less than 0.05 and vice versa.

The output of the SmartPLS is as in table 1 .

Table 1. Path Coefficient

\begin{tabular}{lcc}
\hline \multicolumn{1}{c}{ Path Coefficient } & t-statistic & p-value \\
\hline Product Quality (X1) -> Customer satisfaction (Y1) & 2.561 & 0.005 \\
Product Quality (X1) -> Customer Loyalty (Y2) & 2.867 & 0.002 \\
Restaurant Atmosphere (X2) -> Customer satisfaction (Y1) & 3.458 & 0.000 \\
Restaurant Atmosphere (X2) -> Customer Loyalty (Y2) & 1.709 & 0.044 \\
Customer Value (X3) -> Customer satisfaction (Y1) & 2.527 & 0.006 \\
Customer Value (X3) - C Customer Loyalty (Y2) & 3.793 & 0.000 \\
Customer Satisfaction (Y1) -> Customer Loyalty (Y2) & 2.255 & 0.012 \\
Product Quality $\rightarrow$ Customer satisfaction $\rightarrow$ Customer Loyalty & 1.741 & 0.041 \\
Restaurant Atmosphere $\rightarrow$ Customer satisfaction $\rightarrow$ Customer & 1.726 & 0.042 \\
Loyalty & & 0.032 \\
Customer Value $\rightarrow$ Customer satisfaction $\rightarrow$ Customer Loyalty & 1.853 & 0.04 \\
\hline
\end{tabular}

\subsection{Direct influence}

Hypothesis 1 : Effect of product quality on customer satisfaction

Based on the results of the analysis it can be seen that product quality has a positive and significant effect on customer satisfaction with the results of $\mathrm{p}$-value $0.005<0.050$ and $\mathrm{t}$-staistic value $>\mathrm{t}$-table which is $2.561>1.661$.

The results of this study are supported by previous research conducted by (Nuridin, 2018) entitled "Effect of Service Quality and Quality of Products to Customer loyalty with Customer Satisfaction as Intervening Variable in PT. Nano Coating Indonesia "revealed that product quality has a positive and significant influence on customer satisfaction. This shows that the better the quality given to the customer, the higher the feeling of satisfaction of the customer after buying at the Choie Dimsum Surabaya.

Hypothesis 2 : the effect of product quality on customer loyalty

Based on the results of the analysis, it can be seen that product quality has a positive and significant effect on customer loyalty with the results of $\mathrm{p}$-value $0.002<0.050$ and $\mathrm{t}$-staistik $>\mathrm{t}$-table which is $2.867>1.661$.

This research was supported by the research conducted by (Nuridin, 2018) entitled "Effect of Service Quality and Quality of Products to Customer Loyalty with Customer Satisfaction as Intervening Variable in PT. Nano Coating Indonesia "revealed that product quality has a positive and significant influence on customer satisfaction. This shows 
that with the better quality given to customers, customers will make repeated purchases at Dimsum Choie

Hypothesis 3 Effect of restaurant atmosphere on customer satisfaction

Based on the results of the analysis, it can be seen that the atmosphere of the restaurant has a positive and significant effect on customer satisfaction with the results of $\mathrm{p}$-value $0,000<0.050$ and $\mathrm{t}$-staistic value $>\mathrm{t}$-table which is $3,458>$ 1,661 .

This research is supported by previous research conducted by (Sari \& Wardhana, 2015) with the research title "The Effect of Store Atmosphere on Customer Satisfaction at Roemah Kopi Bandung" saying that Strore Atmosphere simultaneously has a significant effect on customer satisfaction. This shows that with a good place and giving a sense of comfort to the customers, the feeling of satisfaction of the customers will be higher after coming and buying at Dimsum Choie Surabaya.

Hypothesis 4 influences the restaurant atmosphere on customer loyalty

Based on the results of the analysis, it can be seen that customer value has a positive and significant effect on customer loyalty with the results of $\mathrm{p}$-value $0.044<0.050$ and $\mathrm{t}$-staistik $>\mathrm{t}$-table which is $1.709>1.661$.

The results of this study are supported by research conducted by (Purnamasari \& Hidayat 2016) with the research title Analysis of the Effect of Store Atmosphere on Loyalty

Customers at Warung Misbar Bandung in 2016, stated that store atmosphere has a positive and significant effect on customer loyalty of Warung Misbar Kota Bandung. This shows that with a good place and makes it comfortable in the hearts of customers, the higher the level of satisfaction of customers and will make purchases repeatedly.

Hypothesis 5 influences customer value on customer satisfaction

Based on the results of the analysis it can be seen that the customer value has a positive and significant effect on customer satisfaction with the results of $\mathrm{p}$-value $0.006<0.050$ and t-staistik $>\mathrm{t}$-table which is $2.527>1.661$.

This research is supported by previous research conducted by (Candra \& Juliani, 2018) entitled "Impact of E-Service Quality and Customer Value on Customer Satisfaction in LocalBrand" saying that customer value has a significant influence on customer satisfaction. This shows that the better the customer value obtained from the customer, the higher the level of satisfaction of the customer after coming and buying at Dimsum Choie Surabaya.

Hypothesis 6 Effect of customer value on customer loyalty

Based on the results of the analysis it can be seen that the location has a positive and significant effect on customer satisfaction with the results of p-value $0.000<0.050$ and t-staistik $>t$-table which is $13,793>1,661$.

This research is supported by previous research conducted by (Wijayanti \& Wahyono, 2015) with the research title Effect of Service Quality, Customer Perception of Price and Value on Consumer Loyalty Through Customer Satisfaction As Intervening Variables, saying that there is a positive and significant influence on customer loyalty to customer loyalty. This shows that the better the customer value obtained from the customer, the higher the level of customer loyalty is to come and buy repeatedly at Dimsum Choie Surabaya.

Hypothesis 7 Effect of customer satisfaction on customer loyalty

Based on the results of the analysis, it can be seen that customer satisfaction has a positive and significant effect on customer loyalty with the results of $\mathrm{p}$-value $0.012<0.050$ and $\mathrm{t}$-staistik $>\mathrm{t}$-table which is $2.255>1.661$.

This research is supported by previous research conducted by (Montolalalu, 2013) entitled The Impact of Service Quality and Price To Customer Satisfaction And Customer Loyalty in Swiss-Belhotel Maleosan Manado, stating that customer satisfaction has a positive and significant influence on customer loyalty. This shows that more and more customers are satisfied after coming and buying in Choie's dimsum, so the customer will make a repeat purchase. 


\subsection{Indirect Effects}

\section{Product Quality (X1) to Customer Loyalty (Y2) through a Customer Satisfaction (Y1)}

The results of this study indicate that product quality has a positive and significant indirect effect on customer loyalty through purchasing decisions. This is because the value of p-value $0.041<0.050$ and t-statistics $>\mathrm{t}$-table $1.741>1,661$. This shows that the better the quality that is given to the customer, the higher the feeling of satisfaction of the customer after buying in the Choie Dimsum Surabaya, so the customer will make a repeat purchase.

\section{Restaurant Atmosphere (X2) to Customer Loyalty (Y2) through a Customer Satisfaction (Y1)}

The results of this study indicate that the restaurant atmosphere has a positive and significant influence on customer loyalty through customer satisfaction. This is because the p-value is $0.042<0.050$ and t-statistics $>\mathrm{t}$-table $1,726>$ 1,661. This shows that with the best place and giving a sense of comfort to the customer's heart, the higher the feeling of satisfaction of the customer after coming and buying at the Choie Dimsum Surabaya, so the customer will make a repeat purchase.

\section{Customer Value (X3) to Customer Loyalty (Y2) through a Customer Satisfaction (Y1)}

The results of this study indicate that customer value has a positive and significant indirect effect on customer loyalty through customer satisfaction. This is because the p-value is $0.032<0.050$ and $t$-statistics $>\mathrm{t}$-table $1.853>1.661$. This shows that the better the customer value obtained from the customer, the higher the level of satisfaction of the customer after coming and buying at the Surabaya Choir Dimsum, so that the customer will make repeated purchases repeatedly.

\section{Conclusions}

The findings of this study indicate that the direct influence of the independent variables on product quality, restaurant atmosphere, and customer value has a positive and significant effect on customer satisfaction and customer loyalty at the Surabaya Dimsum Choie. For product quality variables, restaurant atmosphere and customer value have a positive and significant indirect effect on customer loyalty through customer satisfaction.

\section{References}

Candra, S., \& Juliani, M. (2018). Impact of E-Service Quality and Customer Value on Customer Satisfaction in LocalBrand. 9(July), 125-132. https://doi.org/10.21512/bbr.v9i2.4650

Griffin, J. (2005). Customer Loyalty. Jakarta: Erlangga.

Hasan, A. (2008). Manajemen Pemasaran dan Marketing. Bandung: Alfabeta.

Kotler dan Amstrong. (2001). Prinsip-prinsip pemasaran Jilid 1 (ke 12). Jakarta: Erlangga.

Kotler dan Keller. (2009). Manajemen Pemasaran. Jilid I. (Ke 13). Jakarta: Erlangga.

Kotler, P. (1995). Manajemen Pemasaran. Jakarta: Erlangga.

Kotler, P. (2000). Manajemen Pemasaran: Analisis Perencanaan Implementasi dan Pengendalian Jilid II. Jakarta: Prenhallindo, Jakar.

Montolal, M. T. (2013). The Impact Of Service Quality And Price To Customer Satisfaction And Customer Loyalty In Swiss-Belhotel Maleosan Manado. Jurnal EMBA: Jurnal Riset Ekonomi, Manajemen, Bisnis Dan Akuntansi, 1(4), 1491-1498. https://doi.org/10.35794/emba.v1i4.2951

Mowen, Jhonn C. dan Michael, M. (2002). Perilaku Konsumen (Lima). Jakarta: Erlangga.

Nuridin. (2018). Effect of service quality and quality of products to customer loyalty with customer satisfaction as 
intervening variable in PT . nano coating Indonesia International Journal of Business and Applied Social Science (IJBASS ). 4(1).

Purnamasari, N. D., Hidayat, A. M., \& Si, M. (2016). Analisis Pengaruh Store Atmosphere Terhadap Loyalitas Pelanggan Pada Warung Misbar Bandung Tahun 2016. EProceedings of Applied Science, 2(2), 441-447.

Sari, N. M., \& Wardhana, A. (2015). Pengaruh Store Atmosphere Terhadap Kepuasan Konsumen Pada Roemah Kopi Bandung. EProceedings of Management, 2(3), 3947-3952.

Sugiyono. (2008). Metode Penelitian Kunatitatif Kualitatif dan R\&D. Bandung: Alfabeta.

Tjiptono, F. (2004). Manajemen Jasa. Yogyakarta: Andi.

Tjiptono, F. (2005). Pemasaran Jasa. Malang: Bayumedia Publishing.

Tjiptono, F. (2008). Strategi Pemasaran (3rd ed.). Yogyakarta: Andi.

Wijayanti, I. W., \& Wahyono. (2015). Pengaruh Kualitas Pelayanan, Persepsi Harga dan Nilai Pelanggan terhadap Loyalitas Konsumen melalui Kepuasan Pelanggan sebagai Variabel Intervening. Management Analysis Journal, 4(1), 50-57. 